\title{
20. EOCENE TO MIOCENE CHRONOSTRATIGRAPHY OF THE QUEENSLAND PLATEAU: CONTROL OF CLIMATE AND SEA LEVEL ON PLATFORM EVOLUTION ${ }^{1}$
}

\author{
C. Betzler, ${ }^{2}$ D. Kroon, ${ }^{3}$ S. Gartner, ${ }^{4}$ and W. Wei ${ }^{5}$
}

\begin{abstract}
The Queensland Plateau carbonate platform (northeastern Australia) is characterized by a complex evolutionary history that has been punctuated by several interruptions in platform growth. The surface of the plateau (metamorphic rocks) was flooded during the middle Eocene marine transgression. For the first time, a carbonate platform was formed in the area. It was characterized by bryozoan-rich deposits, which originated in temperate-to-cool waters. However, some layers within this interval are rich in larger benthic foraminifers that point to warmer-water intrusions. A sea-level lowstand caused a regional unconformity (upper Eocene-lower Oligocene) and concomitant changes in surface-water temperatures. This was followed by a major rise of sea level, and during highstand conditions, a major subtropical-to-tropical buildup was established (upper Oligocene to middle Miocene). Several exposure surfaces within this interval document minor sea-level lowerings. In response to a major sea-level lowstand, the platform became exposed and eroded at the middle/upper Miocene boundary. Final drowning of most of the platform occurred during the late Miocene, initiated by rising sea level and increased subsidence of the basement.
\end{abstract}

\section{INTRODUCTION}

The Queensland Plateau is the largest marginal plateau of the northeastern Australian margin and has a surface of $\sim 165,000 \mathrm{~km}^{2}$ (Davies et al., 1989). Half of the plateau lies above the 1000-m isobath; living reef tracts at or near the sea surface form about $10 \%$ to $15 \%$ of the plateau's surface. Before Leg 133, only one drill site (Site 209, Leg 21; Burns, Andrews, et al., 1973) (Fig. 1) provided information about the lithologic succession of the plateau. However, Site 209 did not penetrate any shallow-water carbonates, and drilled deposits consist of Paleogene sand-bearing foraminiferal oozes and cherts overlain by Neogene foraminiferal and calcareous nannofossil oozes. Combining seismic data with the data from Site 209, Mutter (1977), Taylor and Falvey (1977), and Davies et al. (1989) proposed models for the evolution of the plateau, which detached from the Australian continent during the Late Cretaceous as a response to rifting processes.

More recently, the recovery of dredge samples, consisting of Eocene to Miocene neritic limestones proved the existence of a Paleogene and Neogene carbonate platform in the area of the Queensland Plateau (Chaproniere, 1983). One of the scientific objectives of Leg 133 was to analyze the evolution of this buildup. For this purpose, five sites $(811 / 825,812$ through 814 , and 824$)$ were drilled at different positions on the plateau (Fig. 1).

The purposes of this study are (1) to establish the chronostratigraphy of the Eocene to Miocene buildup phases at the different drilling sites of the Queensland Plateau (Sites 811/825, 812 through 814, and 824 ) and (2) to discuss the main factors that controlled platform evolution during this time.

Dates of the sedimentary successions rely on planktonic foraminifer zonation, larger benthic foraminifer letter stage determination, and calcareous nannoplankton zonation.

\footnotetext{
'McKenzie, J.A., Davies, P.J., Palmer-Julson, A., et al., 1993. Proc, ODP, Sci. Results, 133: College Station, TX (Ocean Drilling Program).

${ }^{2}$ Geologisch Paläontologisches Institut, Senckenberganlage 32-34, 6000 Frankfurt am Main 11, Federal Republic of Germany.

${ }^{3}$ Department of Geology and Geophysics, University of Edinburgh, West Mains Road, Edinburgh EH9 3JW, United Kingdom.

${ }^{4}$ Department of Oceanography, Texas A\&M University, College Station, TX 77843 , U.S.A.

${ }^{5}$ Department of Geology, Florida State University, Tallahassee, FL 32306, U.S.A. (Current address: Scripps Institution of Oceanography, University of California, San Diego, La Jolla, CA 92093-0215.)
}

For the planktonic foraminifer zones, the zonal scheme given by Blow (1969), with modifications by Kennett and Srinivasan (1983), has been employed. The East Indian Letter Stage Classification for the Tertiary, as modified by Adams (1984), Jenkins et al. (1985), Chaproniere (1981, 1984), and Wonders and Adams (1991), was used for the larger benthic foraminifer biostratigraphy. In addition, Parameter F (Chaproniere, 1981, 1984) and Parameter dc (e.g., Van der Vlerk et al., 1973) have been employed for the classification of specimens of Nephrolepidina. For the calcareous nannoplankton zonation, the scheme of Okada and Bukry (1980) was used; this scheme is easily convertible to the Martini (1971) scheme. Ages for the Neogene were applied as given by Berggren, Kent, and Flynn (1985) and Berggren, Kent, and Van Couvering (1985). A detailed description of the planktonic foraminifer zonation and calcareous nannoplankton zonation for the Queensland Plateau sites is given in the biostratigraphy chapters in Davies, McKenzie, Palmer-Julson, et al. (1991).

Determination of sedimentary disconformities is based on microfacies analysis. For intervals having poor or no core recovery, geophysical logs were used to determine lithified vs. nonlithified lithologies. In addition, seismic data from the site survey (Davies, McKenzie, Palmer-Julson, et al., 1991) were used to observe largescale depositional geometries and to generate a subsidence curve for Site 813 .

Our discussion of the chronostratigraphy concentrates on Sites 811/ 825 and 824 (Fig. 2). At both sites, faunal preservation and specimen abundance permit a detailed biostratigraphic analysis of the succession.

\section{BIOSTRATIGRAPHIC SUMMARY}

\section{Site 811/825}

At this site, marine sedimentation initiates with bryozoan-dominated grainstones. A middle Eocene age was assigned to this succession by the following faunal elements: in the lower part of the succession, rare-to-frequent larger benthic foraminifers (Discocyclina and Nummulites) occur (Fig. 3); in the upper part, one pebble of sediment (Sample 133-811B-20X-CC) contained specimens of the planktonic foraminifer Morozovella. However, this was the only lump of sediment recovered in the entire core and may be reworked. This interval was succeeded by unlithified hemipelagic to pelagic oozes having reworked neritic material; these oozes were assigned to the upper Oligocene because of the presence of broken specimens of the larger benthic foraminifer Nephrolepidina (Samples 133-811B-21X$1,40-46 \mathrm{~cm}$, and 133-811B-20X-1, 20-25 cm). 


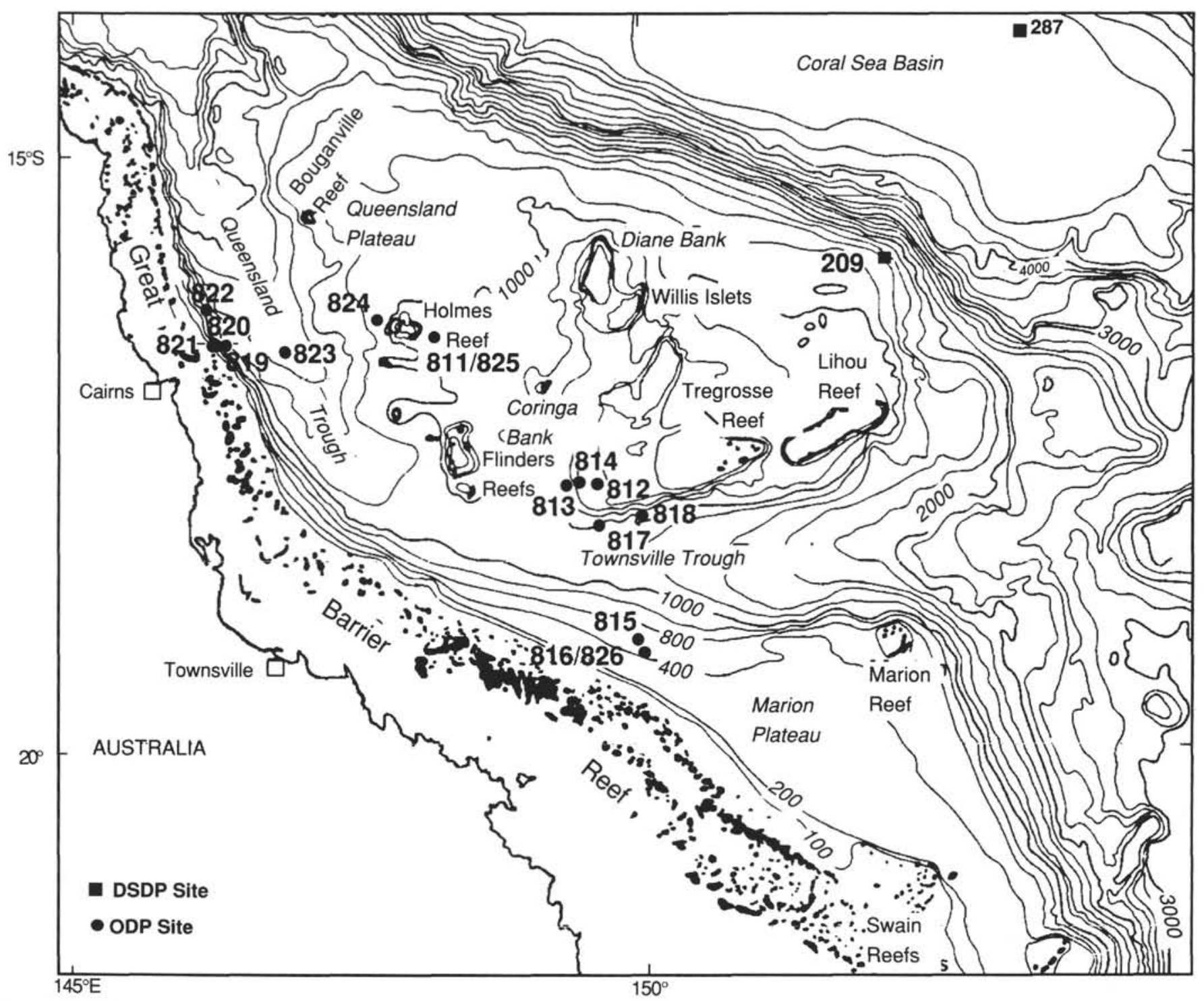

Figure 1. Location map of Leg 133 drill sites and Site 209.

The subdivision of the lower and middle Miocene sequences relies on the analyzed larger benthic foraminifers (Fig. 3). The top of the middle Miocene has been defined by the last occurrence of faunas rich in Nephrolepidina howchini, together with the last occurrence of the calcareous nannofossil Discoaster hamatus (Sample 133-811A$19 \mathrm{H}-\mathrm{CC})$. This last occurrence approximates the middle/upper Miocene boundary.

\section{Site 824}

As at Site $811 / 825$, marine sedimentation at this location began during the Eocene, based on the presence of the larger benthic foraminifers Nummulites and Discocyclina (Fig. 4). Taking into account the minor geographic distance between both sites, one may assume that this lowermost unit is also of middle Eocene age. The middle Eocene strata are overlain by uppermost Oligocene to lower Miocene deposits. This age assignment was based on the presence of an assemblage of planktonic foraminifers (planktonic foraminifer Zone N3-N4, 21.823.7 Ma) that consists of abundant Globigerina ciperoensis, Globigerina praebulloides, and two specimens of Globorotalia kugleri in Sample 133-824A-36X-CC. However, a gap in the core recovery occurs between Cores 133-824C-17X and 133-824A-36X.
The lower and middle Miocene have been defined by the presence of larger benthic foraminifers (Fig. 4). The upper Te and lower to middle Tf stages can be distinguished. The upper Miocene sequences at Site 824 are defined by the occurrence of a CN9b nannoplankton association in Core 133-824A-17X.

\section{Site 812}

Holes drilled at this and the following sites did not penetrate the contact between basement and sediment. The oldest datable sample occurs in Core 133-812B-16R. It contains Nephrolepidina howchini, which indicates a middle Miocene age. The next datum is given by a fauna containing Neogloboquadrina acostaensis, Globoquadrina altispira, and Globoquadrina dehiscens. These specimens indicate the planktonic foraminiferal Zones N16-N18 (upper Miocene and lower Pliocene). The planktonic foraminifers occur together with abundant larger benthic foraminifers (Cycloclypeus and Operculina).

\section{Site 813}

The oldest sediment found in holes drilled at this site consists of dolomites, which do not contain any determinable faunal association. 

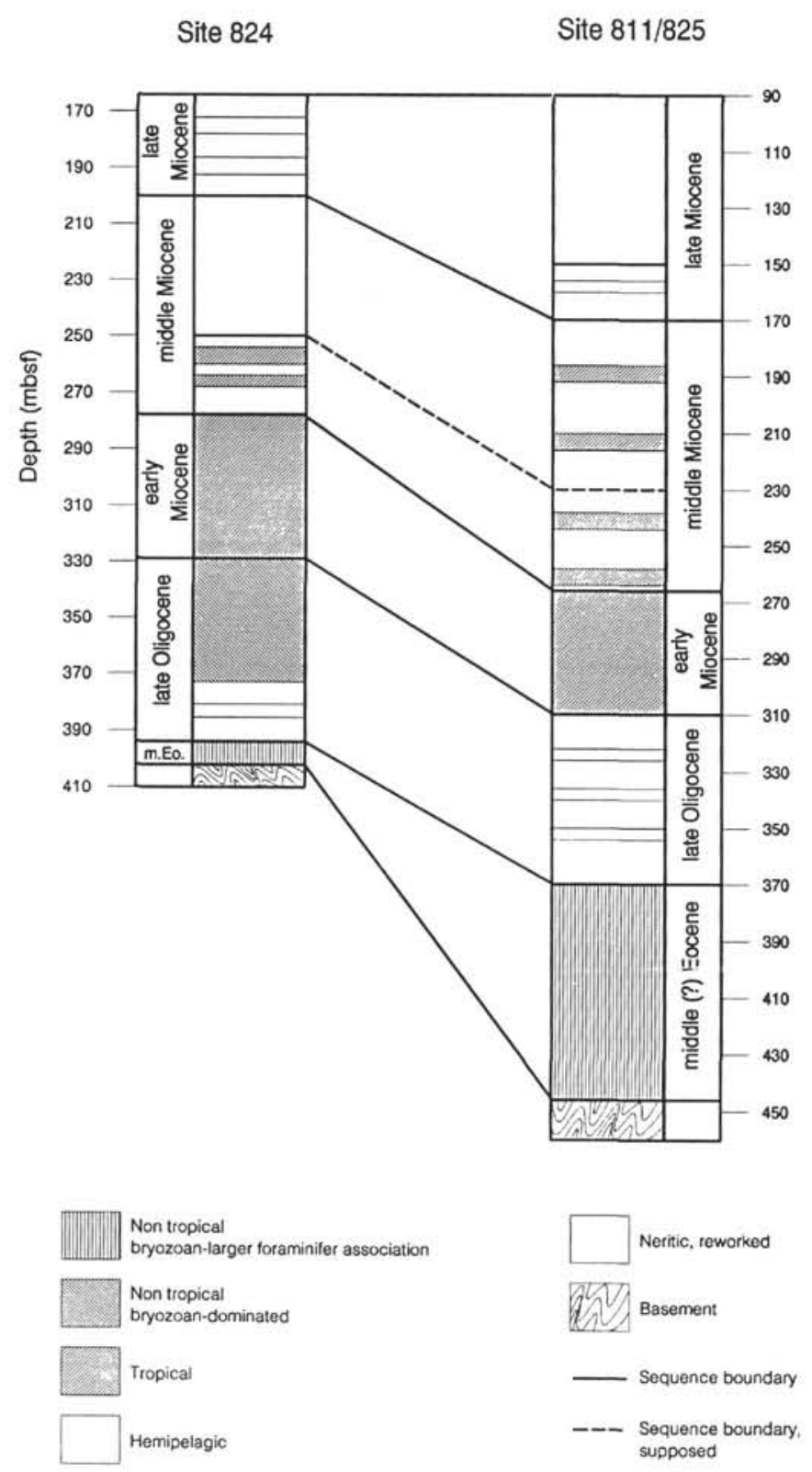

Figure 2. Correlation of Site 811/825 with Site 824 showing main depositional facies associations.

Upper Miocene oozes overlying the dolomitized interval were recorded by the occurrence of the calcareous nannofossil Discoaster quinqueramus (CN9) in Sample 133-813A-19H-CC.

\section{Site 814}

The presence of the larger benthic foraminifer Nephrolepidina howchini (Sample 133-814A-23X-CC) attributes the lower interval at this site to the middle Miocene. The next younger datable fauna occurs in Sample 133-814A-11H-CC. It contains few specimens of the planktonic foraminifers $N$. acostaensis, and Globorotalia tumida tumida is absent, which indicates a late Miocene age.

\section{DEPOSITIONAL UNITS}

The described depositional units are unconformity-bounded sedimentary successions. The definition of the bounding unconformities

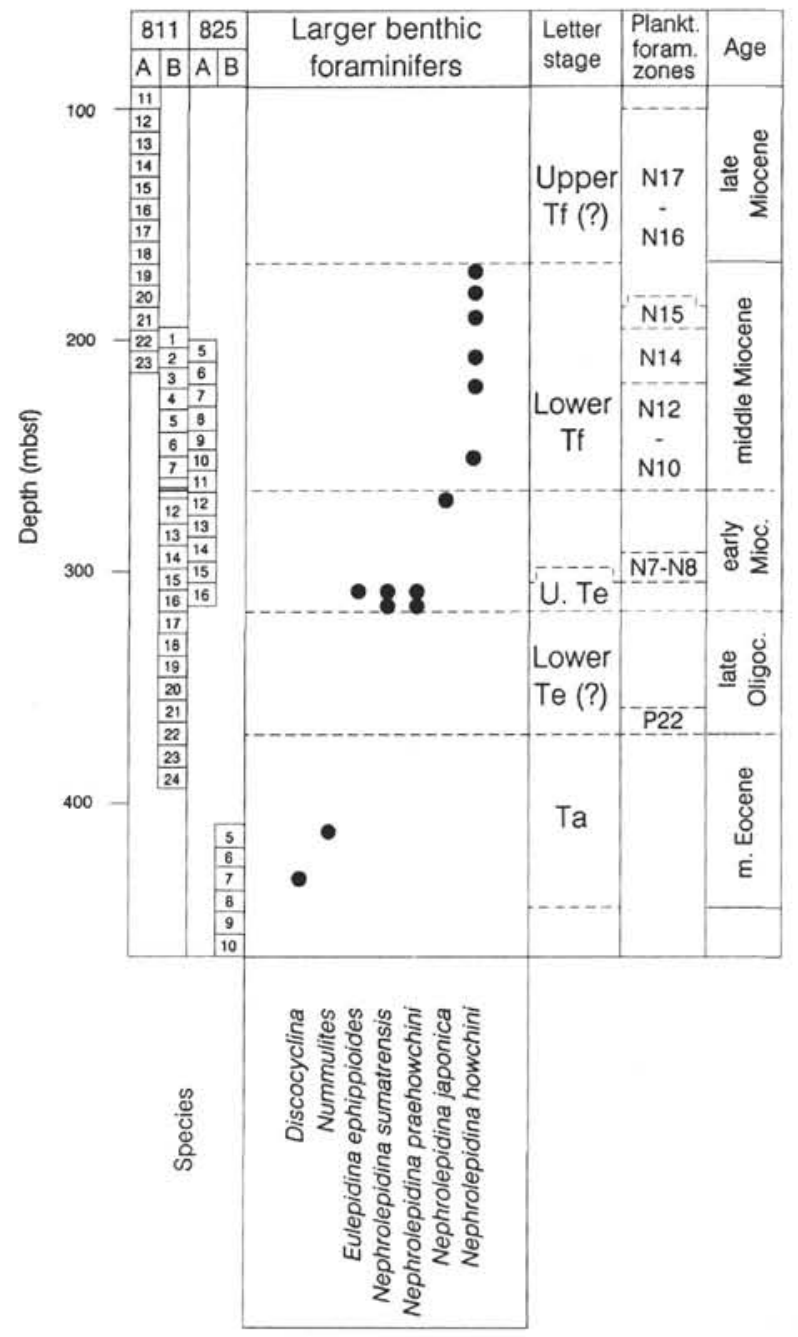

Figure 3. Distribution of age-diagnostic larger benthic foraminifers at Site $811 / 825$.

relies on a combination of biostratigraphic data, microfacies data, and well-log (mainly velocity log) data.

\section{Middle Eocene Unit}

This unit was found at Sites 209, 811/825, and 824; it marks the beginning of marine sedimentation on the Queensland Plateau. The lower bounding unconformity is marked by the contact of the basement rocks with the first Tertiary sediments. The upper bounding unconformity has not been recorded in the cores. However, we postulate that it is marked by a hiatus that encompasses the upper Eocene and parts of the lower Oligocene sections (Fig. 5).

Sediments of the middle Eocene depositional unit are represented by shallow-water deposits (middle to outer neritic). These deposits consist of wackestones to grainstones with abundant bryozoans, rare-to-abundant operculinids, and rare nummulitids. Some intervals contain rare-to-frequent branching red algae.

The deposits are compared with the recent temperate bryozoandominated carbonates from the shelf of eastern Australia, as described by Marshall and Davies (1978), and with those from the New Zealand shelf, as described by Nelson et al. (1988). Fossil examples include Oligocene to Miocene cool-water limestones from southern Australia, as described by James and Bone (1991), and Paleogene carbonate sediments from the Emperor Seamounts, described by McKenzie et al. (1980). The larger benthic foraminifers that occur within this 


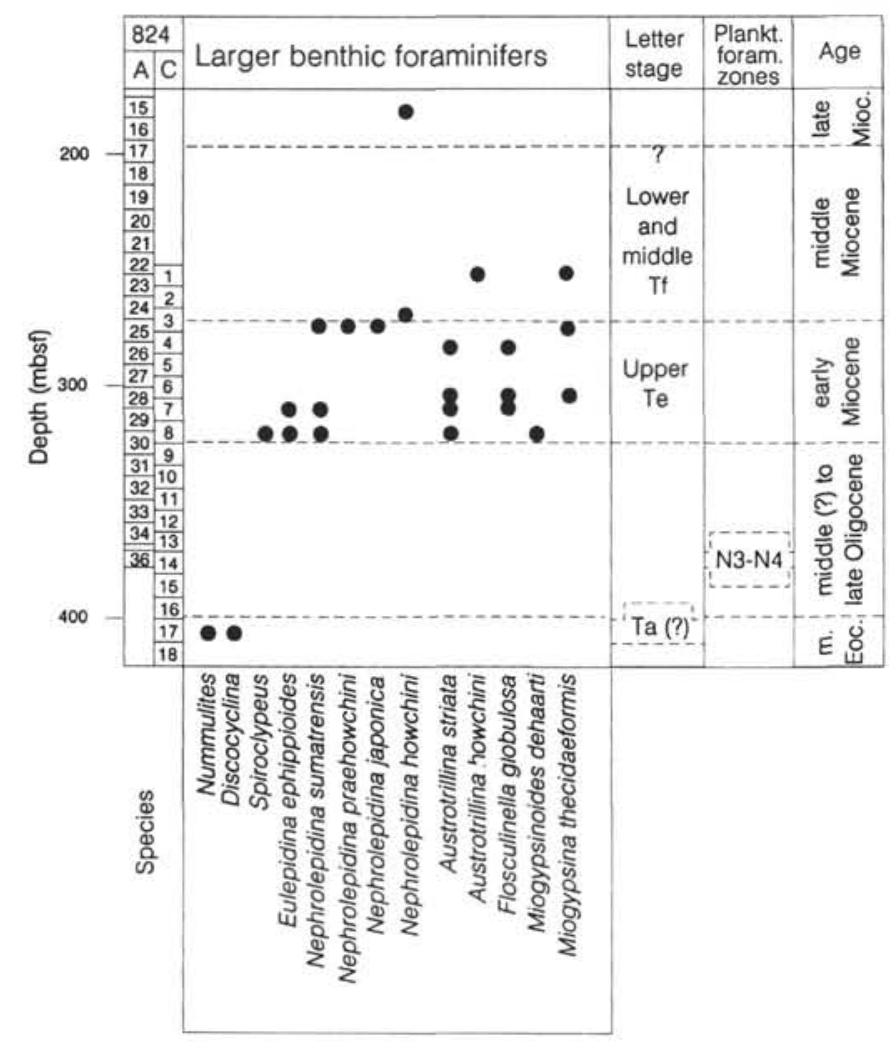

Figure 4. Distribution of age-diagnostic larger benthic foraminifers at Site 824 .

succession may record some warmer-water incursions from the southern and western parts of Australia, as described by McGowran (1986) and McGowran and Beecroft (1986). In this case, the larger benthicforaminifer-bearing facies would form in transitional waters (subtropical to temperate) from the recent middle-to outer-shelf off Brazil, as described by Carannante et al. (1988).

The occurrence of a caliche horizon, with the first development of silcrete features characterized by length-fast chalcedony (compare Summerfield, 1983), in Core 133-825B-8R proves that this first marine ingression was not a response to one single flooding event. More likely, this depositional episode consisted of more than one transgressive-regressive cycle.

\section{Upper Oligocene Unit}

The lower bounding unconformity of this depositional unit is marked by a hiatus between the middle Eocene and the upper Oligocene. The duration of this hiatus (which separates both units) is $\sim 14$ Ma (Fig. 5). At Site 209 (DSDP Leg 21), the duration of this hiatus seems to be slightly shorter (Edwards, 1973). It also should be noted that the age of a first marine transgression in the southern Great Barrier Reef area (Sandy Cape 1-3R drill hole; Palmieri, 1984) roughly coincides with the age $(\mathrm{N} 4 / \mathrm{N} 3)$ of the base of this depositional unit. Taylor and Falvey (1977) showed that this hiatus corresponds to a regional unconformity that also can be traced in deeper parts of the Coral Sea Basin, and Moore et al. (1978) proved its widespread occurrence in the southwest Pacific Ocean.

Sediments of this depositional unit consist of unlithified bryozoandominated packstones (Site 824). At Site 811/825, the age-equivalent deposits were formed by unlithified oozes containing bryozoans, planktonic foraminifers, small benthic foraminifers, and debris of the larger benthic foraminifer Nephrolepidina. They have been inter- preted as recording a depositional setting similar to that of the underlying sediments. The higher abundance of planktonic foraminifers, however, may point to a somewhat deeper depositional setting.

The upper bounding unconformity of this unit is marked by a drastic change in depositional facies: the bryozoan-rich sediments are overlain by neritic limestones with corals and abundant larger benthic foraminifers.

\section{Lower Miocene Unit}

The onset of subtropical-to-tropical, neritic sedimentation marks the lower bounding unconformity of this unit. The upper limit at Site 824 was placed in a layer of a recrystallized wackestone to packstone in Sample 133-824A-24X-CC, having moldic porosity and rare dolomite rhomboeders (Fig. 6A). Pores have been partially filled in with a blocky or scalenoedric cement; some pores exhibit a partial geopetal infill. Syntaxial cement developed around some echinid debris. At Site 811/825, this horizon corresponds to the top of a well-cemented interval ( 267 meters below seafloor [mbsf]) visible in the velocity log.

The sediments of this unit consist mainly of wackestones to rudstones having abundant larger benthic foraminifers (Lepidocyclina, Flosculinella, Miogypsina, and Spiroclypeus), frequent red algae, rare-to-frequent Halimeda, and rare-to-frequent corals. According to Marshall and Davies (1978) and Schlanger (1981), the presence of Halimeda in this type of facies defines them as warm-water deposits. The presence of larger benthic foraminifers permits one to assign the deposits an inner to middle neritic depositional setting.

\section{Lower Middle Miocene Unit}

The bounding unconformities of this unit have been defined at Site 824. The lower limit of this unit corresponds to the top of the lower Miocene unit.

The upper bounding limit consists of a well-cemented hardground having a complex diagenetic history (Sample 133-824C-1R-CC; Figs. $6 \mathrm{C}, 7)$. After the deposition of the bioclasts, a first generation of isopachous fibrous cement lithified the layer. Subsequently, the layer was subjected to solution, a process that resulted in a vuggy and moldic porosity. A minor phase of dripstone cementation also has been assigned to this time interval. In a second cementation step, a closely packed drusy cement, which in places is scalenoedric, precipitated in the vuggy porosity. The remaining pores finally have been totally filled in by a mudstone containing menardiiform planktonic foraminifers.

Partial leaching of this mudstone is probably linked to borings that cut through the whole lithology. These borings have been filled in by a second generation of peloidal mudstone that displays a geopetal arrangement. In places, a thin film of fine crystal silt occurs between the drusy and scalenoedric crystals at the roofs of the pores (vadose silt?).

We suggest that this hardground reflects a sequence of marine cementation, followed by meteoric diagenesis and a final drowning event that resulted in a marine hardground with borings.

The larger benthic foraminifer association and the planktonic foraminifers in the borings (Globorotalia praemenardii?) permit one to assign this unconformity an early middle Miocene age.

The correlation of this horizon at Site 824 with that at Site 811/825 is less straightforward. We propose that the same flooding event was responsible for the first increase of calcareous nannoplankton abundance at this site (see site chapters in Davies, McKenzie, Palmer-Julson, et al., 1991).

The sedimentary succession of this unit, which consists of planktonic foraminifer and calcareous nannoplankton oozes, generally indicates deposition in a slightly deeper setting than during the previous unit (abundant planktonic foraminifers). 


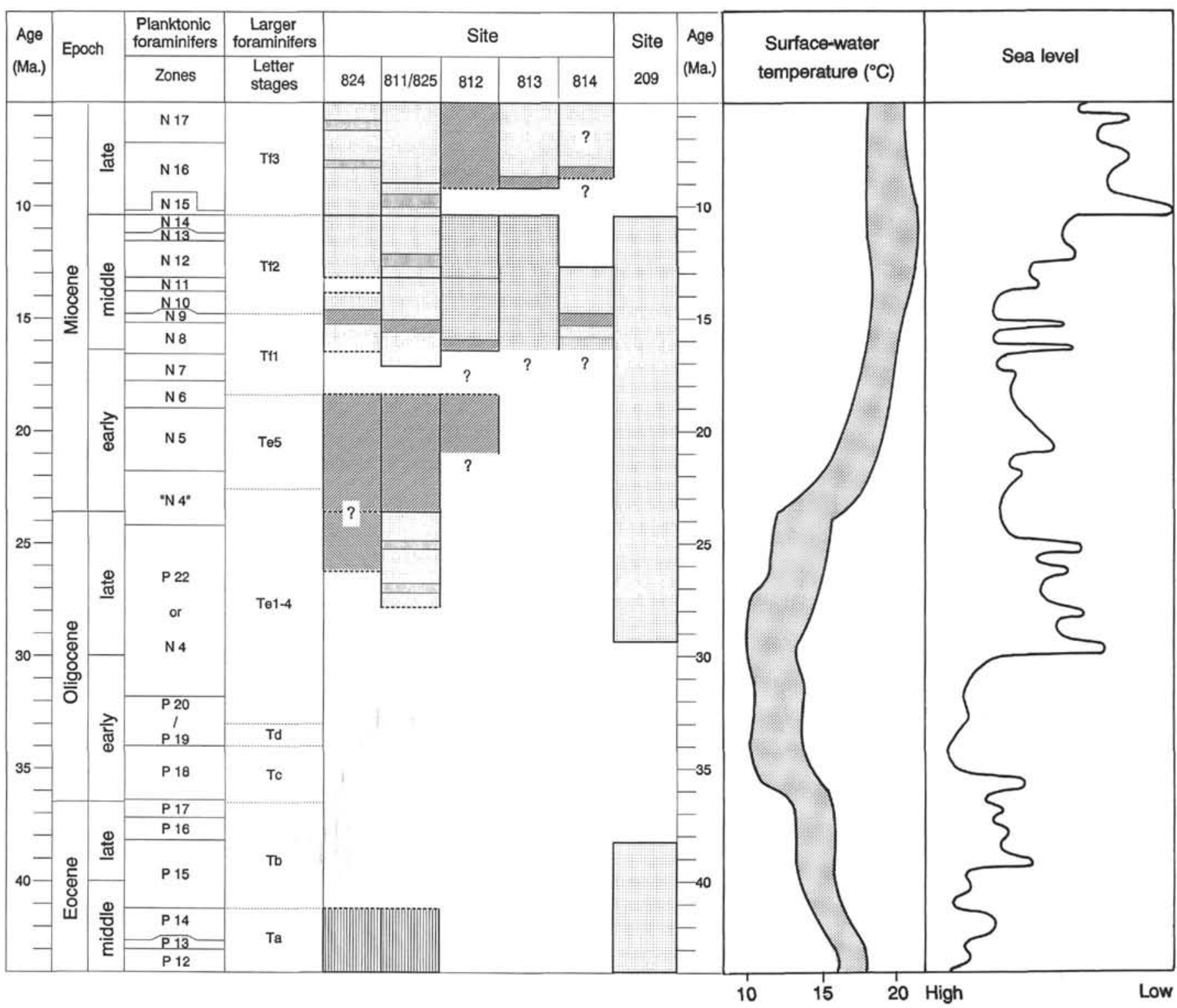

Dolomite

Figure 5. Chronostratigraphy of the Eocene to Miocene interval at the Queensland Plateau (Sites 811/825, 812 through 814, 824, and 209), with calculated surface-water temperature values for northeastern Australia (modified after Feary et al., 1991) and global changes in sea level according to Haq et al. (1988). The duration for hiatuses in the upper Miocene at Sites 812 through 814 is interpretative. Interpretation is based on the onlap configuration on BMR seismic line 75/057 (see Fig. 8), because low diverse planktonic foraminifer faunas with few specimens impede exact age assignments in this part of the succession. Large-scale trends of sea-level fluctuations are reflected in the position of major unconformities, but a one-to-one correlation of the unconformity-bounded sedimentary cycles with the global third-order sea-level cycles is not possible. For legend, see Figure 2. Absolute ages according to authors cited in the text.

\section{Upper Middle Miocene Unit}

This depositional unit consists of the remainder of the middle Miocene section. The top of the unit is marked by a strong increase in nannoplankton abundance at $170 \mathrm{mbsf}$ (Site $811 / 825$; see site chapters in Davies, McKenzie, Palmer-Julson, et al., 1991). Sedimentation during this time interval has been characterized by foraminifer oozes having layers of reworked neritic material (Site 811/825) with abundant Nephrolepidina howchini.

\section{Upper Miocene Unit}

During the late Miocene, pelagic conditions were completely restored at Sites $811 / 825$ and 824 based on the occurrence of planktonic foraminifer and calcareous nannoplankton oozes. This evolution can be correlated with a progressive flooding of the platform at the transect of Sites 812 through 814 . This event is reflected both in the biostratigraphy and seismic sequence configuration, which indicate onlapping of the upper Miocene onto the middle Miocene (Fig. 8). 

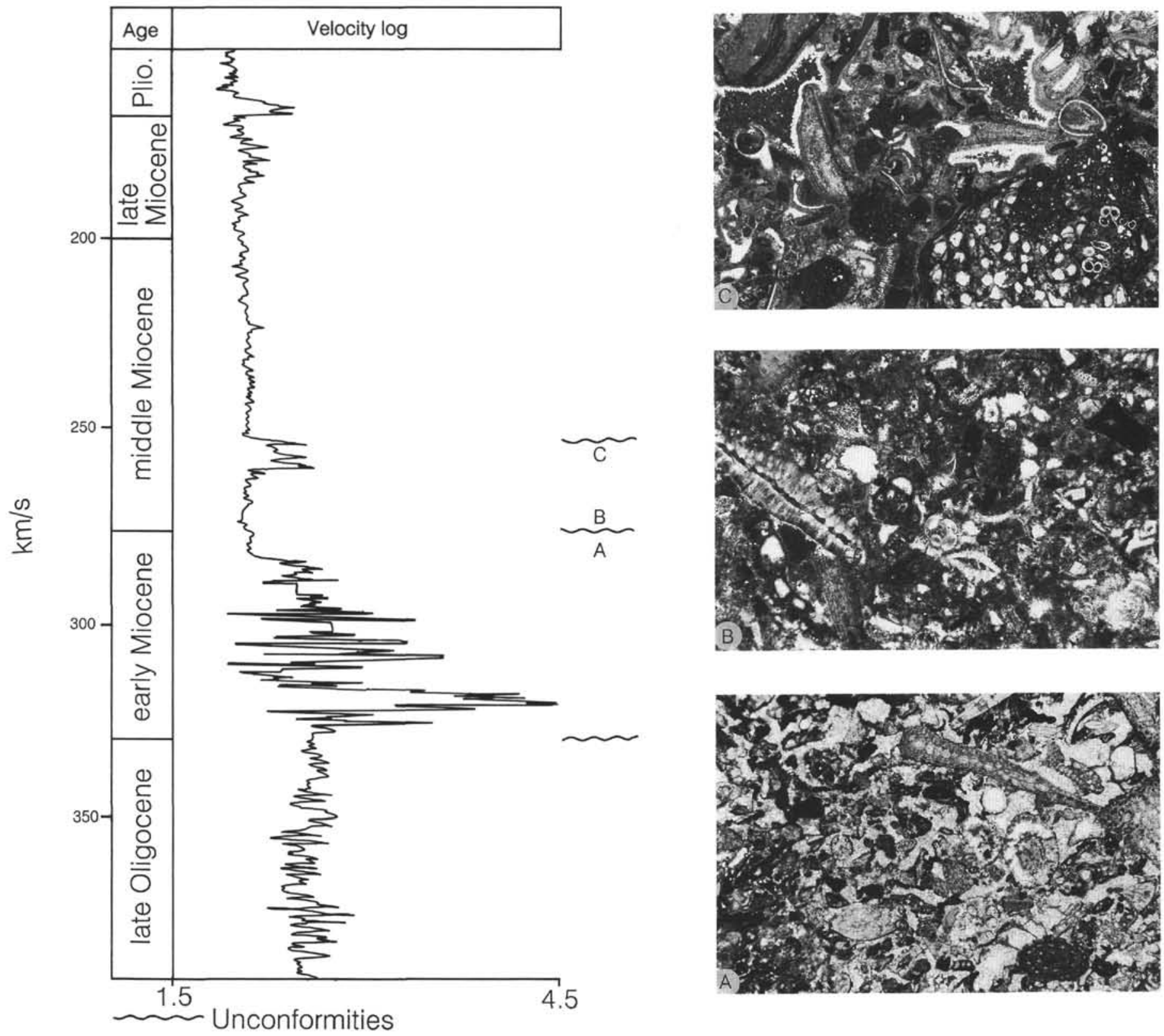

Figure 6. Velocity log for Site 824 with thin-section photos of important unconformities. A. Upper bounding unconformity of the lower Miocene unit. Packstone with larger benthic foraminifers, calcareous green algae (dasycladacean algae), and moldic porosity; Sample 133-824A-24X-CC, $\times 20$. B. Floatstone with Cycloclypeus overlying the upper bounding unconformity of the lower Miocene unit. Note the difference in respect to the diagenetic overprinting compared with (A); Sample 133-824A-24X-CC, $\times 20$. C. Intramiddle Miocene unconformity; Sample 133-824C-1R-CC, $\times 10$.

\section{DISCUSSION}

The chronostratigraphic analysis of the Queensland Plateau, as it is presented here, shows that the Eocene to Miocene sedimentary succession contains unconformities that reflect interruptions of platform growth. Two factors that affected the depositional facies and generated unconformities can be discerned from the sedimentological record: climate and fluctuations in sea level.

\section{Climate}

Climate has affected the Queensland Plateau carbonate platform in two respects. Major surface-water temperature changes occurred during the Eocene-Oligocene interval that affected the skeletal composition of the carbonates of the Marion Plateau and the Queensland
Plateau, as predicted by Feary et al. (1991). Intermediate-to-cool surface waters during the Eocene generated cool-to-transitionalwater, bryozoan-dominated, aragonitic poor-to-free associations. As in the southern and western Australian realms, warm-water intrusions during this time have been recorded by facies rich in larger benthic foraminifers. The onset of tropical convergence off northeastern Australia during the Miocene (Edwards, 1975) finally resulted in subtropical-to-tropical faunal and floral assemblages (corals, larger benthic foraminifers, Halimeda).

Cold-water masses affecting the southeastern Australia region as a consequence of the onset of circum-Antarctic circulation (Kennett, 1977) also may have exerted control on the major hiatus at the Paleogene/Neogene boundary. A comparison of the surface-water temperature variation for the nearshore northeastern Australia region (Fig. 5) with the position and duration of this hiatus shows that the 


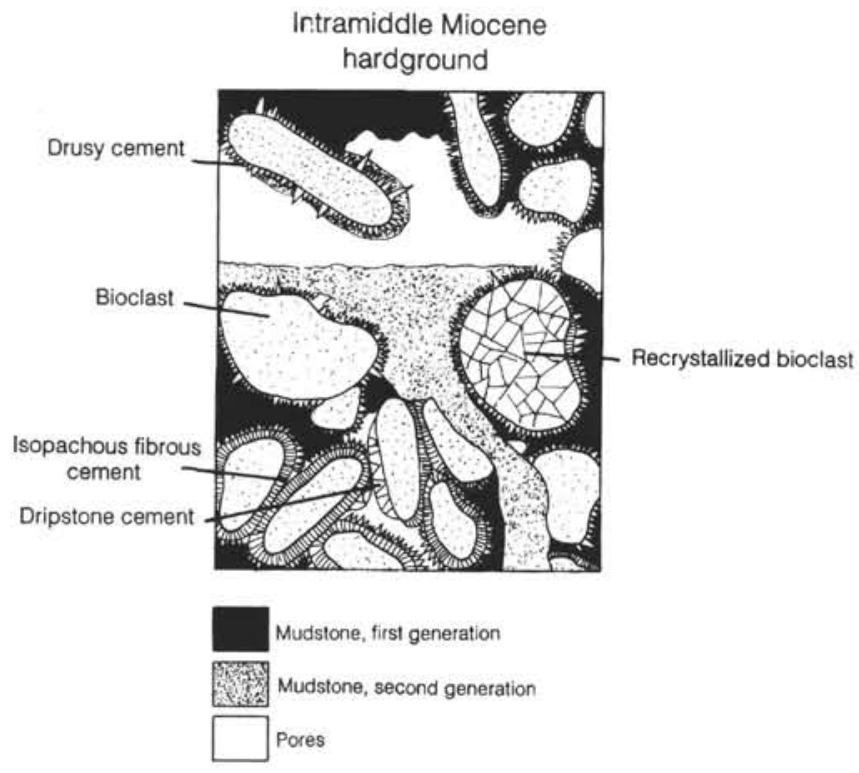

Figure 7. Types of cement of the intramiddle Miocene unconformity at Site 824 (Sample 133-824C-1R-CC, $\times 48$ ). A first generation of isopachous fibrous cement lithified this layer. Eventually, leaching produced a vuggy and moldic porosity. Minor dripstone cements may be linked to this process. Porosity was subsequently infilled by peloidal mudstone (first generation). Borings filled in with a second peloidal mudstone generation cross cut the layer. See text for further explanation.

time of this nondeposition coincided with a decrease in and general low surface-water temperatures.

\section{Changes in Sea Level}

A one-to-one correlation of the Eocene to Miocene unconformitybounded Queensland Plateau sedimentary cycles with the global third-order sea-level cycles (Haq et al., 1988) is not possible (Fig. 5). This is mainly a consequence of the low dating accuracy in the neritic intervals, where the larger benthic foraminifer zonation was used for age assignments. However, the general trend of long-term sea-level changes for this time is confirmed. Fluctuations in sea level, which affected the Eocene to Miocene succession of the Queensland Plateau, have been recorded in the depositional facies as well as in the seismic stratigraphic record.

A complex sea-level history during the Eocene has been documented by the occurrence of silcretes, which point to episodes of immersion. Within the remainder of the stratigraphic succession, the diagenetic overprinting of the following layers points to sea-level lowstands:

1. The unconformity that separates the lower from the middle Miocene (Fig. 6A) displays signs of meteoric diagenesis (moldic porosity, recrystallization).

2. Another well-documented sea-level-controlled unconformity is the intramiddle Miocene hardground at Site 824 (Fig. 6C). The flooding event, which generated the condensation, caused borings to be filled with planktonic foraminifers. This was preceded by a meteoric diagenetic phase. A moldic and vuggy porosity, together with the formation of dripstone cement, points to this process.

Two seismic lines (line BMR 75/057 and the JOIDES Resolution site-survey line; Davies, McKenzie, Palmer-Julson, et al., 1991) situated in the southern part of the Queensland Plateau (Sites 812 through 814 ) provide the large-scale depositional geometries within this area. The lines show a transect through the inner to outer zones of a small middle Miocene buildup of this area. Sites 812 and 814 are located on this buildup, whereas Site 813 documents the sedimentary succession in a more distal position. These holes make it possible for us to tie core and well-log data into the seismic sections down to the lower part of the middle Miocene. Seismic data are good for the middle Miocene to Pleistocene interval. The loss in quality below the middle Miocene and lack of core or log data below this level make interpreta-

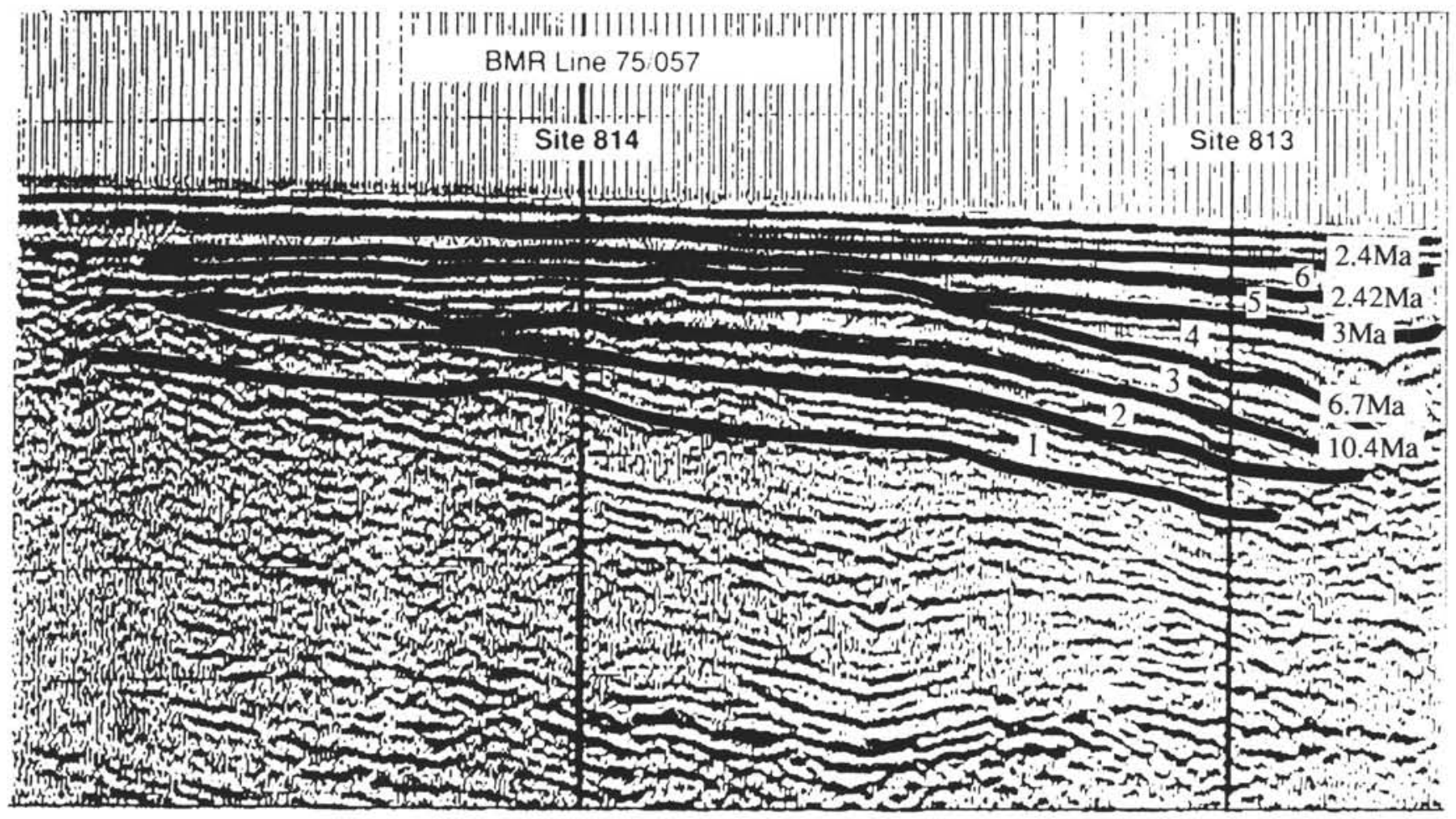

Figure 8. Seismic line BMR 75/057 with positions of Site 813 and Site 814 (modified after Davies, McKenzie, Palmer-Julson, et al., 1991). Seven sequences are shown with ages referring to sequence boundaries. See text for further explanation. 
tion for the lower part of the sections more difficult. The following discussion concentrates on the middle Miocene to Pliocene interval.

An interpretation of the seismic line BMR 75/057 is presented in Figure 8. The seismic sequences were defined on the bases of onlap and downlap terminations and truncations. Seven seismic sequences are correlated to the lithologic units as defined in Davies, McKenzie, Palmer-Julson, et al. (1991).

Two sea-level lowstands are well-documented on both lines. The older one occurs during the middle Miocene between 14.2 and 10.2 $\mathrm{Ma}$. It is represented by a basinward shift in onlap. Benthic foraminiferal associations in the deposits overlying the sequence boundary point to a middle neritic depositional depth (M. Katz, pers. comm., 1991). The sediments of this succession are arranged in a backstepping to aggrading pattern, and the whole succession formed in a middle neritic environment.

The younger sea-level lowstand occurred during the late Miocene (between 6.7 and $3 \mathrm{Ma}$ ) and is reflected in a small sedimentary wedge that onlaps the buildup and does not cover the platform (Fig. 8).

Although sea level was higher during deposition of Sequence 3, as indicated by the platformward shift of onlap, no proofs for actively growing reefs occur in the lithologic succession. Possible explanations for the suppression of reef growth may be associated with regional paleoceanographic changes. These include higher phosphate concentrations in the water (Loutit et al., 1983) or changes in watermass circulation, as indicated by the presence of left-coiling Neogloboquadrina "acostaensis" during this interval. A combination of these effects with a higher subsidence rate between 6 and $7 \mathrm{Ma}$ resulted in an increase of accommodation space and led to a partial drowning of the Queensland Plateau carbonate platform. Further, these effects determined the position of the relict reefs that form the cores of the still actively growing reefs.

\section{ACKNOWLEDGMENTS}

C. Betzler acknowledges financial support by the DFG (grant No. Be 1272/2-2). D. Kroon was supported by NERC (Grant No. GST/ 02/524). We thank John Ardill, Dave Bowen, Simon Bradley, Neil McMahon, Claire Nisbet, Lianne Noble, and Jonathan Turner for their help during the writing of this manuscript. The manuscript benefited from remarks by Kate Darling, and we appreciate the reviews by W. Sliter and T. Gibson.

\section{REFERENCES}

Adams, C.G., 1984. Neogene larger foraminifera, evolutionary and geological events in the context of datum planes. In Ikebe, N., and Tsuchi, R. (Eds.), Pacific Neogene Datum Planes: Contributions to Biostratigraphy and Chronology: Tokyo (Univ. of Tokyo Press), 47-67.

Berggren, W.A., Kent, D.V., and Flynn, J.J., 1985. Jurassic to Paleogene: Part 2. Paleogene geochronology and chronostratigraphy. In Snelling, N.J. (Ed.), The Chronology of the Geological Record. Geol. Soc. London Mem., 10:141-195.

Berggren, W.A., Kent, D.V., and Van Couvering, J.A., 1985. The Neogene: Part 2. Neogene geochronology and chronostratigraphy. In Snelling, N.J. (Ed.), The Chronology of the Geological Record. Geol. Soc. London Mem., 10:211-260.

Blow, W.H., 1969. Late middle Eocene to Recent planktonic foraminiferal biostratigraphy. In Brönniman, P., and Renz, H.H. (Eds.), Proc. First Int. Conf. Planktonic Microfossils, Geneva, 1967: Leiden (E.J. Brill), 1:199-422.

Burns, R.E., Andrews, J.E., et al., 1973. Init. Repts. DSDP, 21: Washington (U.S. Govt. Printing Office).

Carannante, G., Esteban, M., Milliman, J.D., and Simone, L., 1988. Carbonate lithofacies as paleolatitude indicators: problems and limitations. Sediment. Geol., 60:333-346.

\footnotetext{
Abbreviations for names of organizations and publications in ODP reference lists follow the style given in Chemical Abstracts Service Source Index (published by American Chemical Society).
}

Chaproniere, G.C.H., 1981. Australasian mid-Tertiary larger foraminiferal associations and their bearing on the East Indian Letter Classification. BMR J. Aust. Geol. Geophys., 6:145-151.

-1983. Tertiary larger foraminiferids from the northwestern margin of the Queensland Plateau, Australia. Bull.-Bur. Miner. Resour, Geol. Geophys. (Aust.), 217:31-57.

, 1984. Oligocene and Miocene larger foraminiferida from Australia and New Zealand. Bull.-Bur. Miner. Resour, Geol. Geophys. (Aust.). 188:1-98.

Davies, P.J., McKenzie, J.A., Palmer-Julson, A., et al., 1991. Proc. ODP, Init. Repts., 133: College Station, TX (Ocean Drilling Program).

Davies, P.J., Symonds, P.A., Feary, D.A., and Pigram, C., 1989. The evolution of the carbonate platforms of northeast Australia. In Crevello, P.D., Wilson, J.L., Sarg, J.F., Read, J.F. (Eds.), Controls on Carbonate Platform and Basin Development. Spec. Publ.-Soc. Econ. Paleontol. Mineral., 44:233-258.

Edwards, A.R., 1973. Southwest Pacific regional unconformities encountered during Leg 21. In Burns, R.E., Andrews, J.E., et al., Init. Repts. DSDP, 21: Washington (U.S. Govt. Printing Office), 701-720.

, 1975. Southwest Pacific Cenozoic paleogeography and an integrated Neogene paleocirculation model. In Andrews, J.E., Packham, G., et al., Init. Repts. DSDP, 30: Washington (U.S. Govt. Printing Office), 667-684.

Feary, D.A., Davies, P.J., Pigram, C.J., and Symonds, P.A., 1991. Climatic evolution and control on carbonate deposition in Northeast Australia. Palaeogeogr., Palaeoclimatol., Palaeoecol., 89:341-361.

Haq, B.U., Hardenbol, J., and Vail, P.R., 1988. Mesozoic and Cenozoic chronostratigraphy and cycles of sea-level change. In Wilgus, C.K., Hastings, B.S., Kendall, C.G.St.C., Posamentier, H.W., Ross, C.A., and Van Wagoner, J.C. (Eds.), Sea-Level Changes-An Integrated Approach. Spec. Publ.-Soc. Econ. Paleontol. Mineral., 42:71-108.

James, N.P., and Bone, Y., 1991. Origin of a cool-water, Oligo-Miocene deep shelf limestone, Eucla Platform, southern Australia. Sedimentology, 38:323-341.

Jenkins, D.G., Bowen, D.Q., Adams, C.G., Shackleton, N.J., and Brassell, S.C., 1985. The Neogene: Part 1. In Snelling, N.J. (Ed.), The Chronology of the Geological Record. Geol. Soc. London Mem., 10:199-210.

Kennett, J.P., 1977. Cenozoic evolution of Antarctic glaciation, the circumAntarctic Ocean, and their impact on global paleoceanography. J. Geophys. Res., 82:3843-3860.

Kennett, J.P., and Srinivasan, M.S., 1983. Neogene Planktonic Foraminifera: A Phylogenetic Atlas: Stroudsburg, PA (Hutchinson Ross).

Loutit, T.S., Kennett, J.P., and Savin, S.M., 1983. Miocene equatorial and southwest Pacific paleoceanography from stable isotope evidence. Mar. Micropaleontol., 8:215-233.

Marshall, J.F., and Davies, P.J., 1978. Skeletal carbonate variations on the continental shelf of eastern Australia. BMR J. Aust. Geol. Geophys., 3:85-92.

Martini, E., 1971. Standard Tertiary and Quaternary calcareous nannoplankton zonation. In Farinacci, A. (Ed.), Proc. 2nd Int. Conf. Planktonic Microfossils Roma: Rome (Ed. Tecnosci.), 2:739-785.

McGowran, B., 1986. Cainozoic oceanic and climatic events: the Indo-Pacific foraminiferal biostratigraphic records. Palaeogeogr., Palaeoclimatol., Palaeoecol., 55:247-265.

McGowran, B., and Beecroft, A., 1986. Neritic, southern extratropical foraminifera and the terminal Eocene event. Palaeogeogr., Palaeoclimatol., Palaeoecol., 55:23-34.

McKenzie, J.A., Bernoulli, D., and Schlanger, S.O., 1980. Shallow-water carbonate sediments from the Emperor Seamounts: their diagenesis and paleogeographic significance. In Jackson, E.D., Koizumi, I., et al., Init. Repts DSDP, 55: Washington (U.S. Govt. Printing Office), 415-455.

Moore, T.C., Jr., van Andel, T.H., Sancetta, C., and Pisias, N., 1978. Cenozoic hiatuses in the pelagic sediments. Micropaleontology, 24:113-138.

Mutter, J.C., 1977. The Queensland Plateau. Bull.-Bur. Miner. Resour., Geol. Geophys. (Aust.), 179.

Nelson, C.S., Keane, S.L., and Head, P.S., 1988. Non-tropical carbonate deposits on the modern New Zealand shelf. Sediment. Geol., 60:71-94.

Okada, H., and Bukry, D., 1980. Supplementary modification and introduction of code numbers to the low-latitude coccolith biostratigraphic zonation (Bukry, 1973; 1975). Mar. Micropaleontol., 5:321-325.

Palmieri, V., 1984. Neogene foraminiferida from GSQ Sandy Cape 1-3R bore, Queensland: a biostratigraphic appraisal. Palaeogeogr., Palaeoclimatol., Palaeoecol., 46:165-183.

Schlanger, S.O., 1981. Shallow-water limestones in oceanic basins as tectonic and paleoceanographic indicators. Spec. Publ.-Soc. Econ. Paleontol. Mineral., 32:209-226. 
Summerfield, M.A., 1983. Petrography and diagenesis of silcrete from the Kalahari Basin and Cape coastal zone, Southern Africa. J. Sediment. Petrol., 53:895-909.

Taylor, L., and Falvey, D.C., 1977. Queensland Plateau and Coral Sea Basin: stratigraphy, structure and tectonics. APEA J., 17:13-29.

Van der Vlerk, J.M., de Bock, J.F., and Sirotti, A., 1973. Biometrical investigations on Operculina and Lepidocyclina. Boll. Soc. Paleontol. Ital., 11:86-99.
Wonders, A.A.H., and Adams, C.G., 1991. The biostratigraphical and evolutionary significance of Alveolinella praequoyi sp. nov. from Papua New Guinea. Bull. Br. Mus. Nat. Hist., 47:169-175.

Date of initial receipt: 20 April 1992

Date of acceptance: 14 January 1993

Ms 133SR-211 